\title{
Determination of Vanadium (IV) and (V) in Southern Nevada Groundwater by Ion Chromatography-Inductively Coupled Plasma Mass Spectrometry
}

\author{
Sujanie V. Gamage ${ }^{*}, 1$ Vernon F. Hodge ${ }^{1}$, James V. Cizdziel $^{2}$ and Kazumasa Lindley ${ }^{3}$ \\ ${ }^{I}$ Department of Chemistry, University of Nevada, Las Vegas, 4505 S. Maryland Parkway, Las Vegas, NV 89154, USA \\ ${ }^{2}$ Department of Chemistry and Biochemistry, University of Mississippi, MS 38677, USA \\ ${ }^{3}$ Harry Reid Center for Environmental Studies, University of Nevada, Las Vegas, NV 89154, USA
}

\begin{abstract}
A rapid method is presented for measuring $\mathrm{V}(\mathrm{IV})$ and $\mathrm{V}(\mathrm{V})$ in groundwater, without preconcentration or complexing agents, using direct injection of the water samples (which were collected under an argon atmosphere) into an ion chromatograph-inductively coupled plasma mass spectrometer (ICPMS). The mobile phase is $1.5 \% \mathrm{v} / \mathrm{v}$ nitric acid, which minimizes the buildup of solids in the ultrasonic nebulizer, the torch, and on the entrance cones of the ICPMS - a problem with methods using organic complexing agents and inorganic salts. The result is much less instrument downtime for cleaning the affected parts. Limits of detection are $0.02 \mu \mathrm{g} \mathrm{L} \mathrm{L}^{-1}$ for $\mathrm{V}(\mathrm{IV})$ and $0.06 \mu \mathrm{g} \mathrm{L}{ }^{-1}$ for $\mathrm{V}(\mathrm{V})$. The pentavalent form of vanadium represents $98 \%$ to $99 \%$ of the vanadium in these Southern Nevada groundwater samples and ranges from $3.7 \pm 0.1 \mu \mathrm{g} \mathrm{L}^{-1}$ to $82.1 \pm 0.5 \mu \mathrm{g} \mathrm{L}^{-1}$. The remaining few percent is V(IV). Total vanadium was determined by ICPMS for a mass-balance comparison.
\end{abstract}

Keywords: Vanadium speciation, V(IV), V(V), IC-ICPMS, Groundwater, Argon collection.

\section{INTRODUCTION}

Anthropogenic vanadium enters the environment mainly from the burning of fossil fuels, such as residual oils and coal, and, from the production of steel and the manufacture of pigments and paints [1-5]. Vanadium has been shown to be an essential element in humans, playing an important role in the regulation of enzymes such as ATPase, phosphoryltransfer enzymes, adenylate cyclase and protein kinases [46]. Vanadium can exist in oxidation states from (II) to (V) in aqueous solution $[1,2,4]$. Pentavalent vanadium is more toxic than other oxidation states $[1,2,4,5]$. Chronic exposure to inorganic forms of vanadium may result in hematopoietic changes, nephrotoxicity, and reproductive and developmental toxicity [1,6]. Vanadium pentoxide aerosols are "possibly carcinogenic to humans" [1,6,7]. Vanadium is an environmentally important trace element because of its redox sensitivity [2,8-10].

Total vanadium concentrations in groundwater are generally from 0.5 to $2.5 \mu \mathrm{gL}^{-1}$ (ppb) [6,11]. However, the total vanadium in groundwater from volcanic areas in Italy ranges up to $140 \mu \mathrm{g} \mathrm{L}^{-1}$ [4], and, the concentrations in Argentinean groundwater extend from 50 to $2470 \mu \mathrm{g} \mathrm{L}^{-1}$ [3]. The most common oxidation states of vanadium in aqueous systems are $\mathrm{V}(\mathrm{IV})$ and $\mathrm{V}(\mathrm{V})[1,5,12,13]$. The concentrations of vanadium are reported to decrease from oxidizing to reducing environments $[1,4,5]$. In oxidizing waters, the dominant vanadium species are the "phosphate-like anions"

*Address correspondence to this author at the Department of Chemistry, University of Nevada, Las Vegas, NV 89154, USA; Tel: +1-702-895-3845; Fax:+1-702-895-4072; E-mail: gamages@unlv.nevada.edu
$\mathrm{H}_{2} \mathrm{VO}_{4}^{-}$and $\mathrm{HVO}_{4}^{-2}[1,11]$. In reducing environments, vanadyl ion $\mathrm{VO}^{+2}$ is the most stable oxycation $[1,11]$. The existence of each oxidation state species depends on the $\mathrm{pH}$, redox potential and ionic strength of the aqueous system $[1,4,5]$. For these reasons, sample collection and storage techniques must be conducted in a manner that guarantees that the measured species are those representative of the groundwater that was sampled $[5,13]$.

Many techniques have been used to separate the redox species of vanadium in natural waters, including capillary electrophoresis (CE) [14-18], reversed-phase liquid chromatography (RPLC) [19-22] (including ion-pairing (IP) RPLC), and, various forms of ion chromatography $[1,3,4,14$, 15,23-26]. After the species have been separated by any of these techniques, they are quantified by UV [14,17], chemiluminescence [27], ICP [28], or ICPMS [14].

In $\mathrm{CE}$, the vanadium species are separated after complexation with various reagents such as ethylenediaminetetraacetic acid (EDTA) [14,18], diethylenetriaminepentaacetic acid (DTPA) [14,18], and a Mo(VI)-P(V) reagent [17]. In reversed-phase liquid chromatography [2,19-22], the chelating reagents include 4-(2-pyridylazo) resorcinol (PAR) [19-22,29], 2-(5-bromo-2-pyridylazo)-5-(N-propyl-N-sulfopropylamino)-phenol (5-Br-PAPS) [2], hydrogen peroxide-2(5-bromo-2-pyridylazo)-5-diethylaminophenol (5-Br-PADAP) [21] and 2-(5-nitro-2-pyridylazo)-5-[N-n-propyl-N-(3-sulfopropyl)-amino]phenol (nitro-PAPS) [30]. Some of the ionpairing reagents used in IP-RPLC are aminopolycarboxylic acids; e.g. EDTA) [1,2,4,12,14], 1,2-cyclohexanediaminotetraacetic acid (CDTA) [3], N-2-hydroxyethylethylenediaminetetraaceatic acid (HEDTA) [23] and 4-(2-pyridylazo) resorcinol (PAR) [15,24]. 
The major problem in RPLC and CE coupled with ICPMS is due to the organic complexing agents and other reagents used in the methods [13]. These organic compounds can clog the torch and cause instability in the plasma, which can lead to measurement problems and extinction of the plasma. They can also cause residue build-up on the entrance cones of the mass spectrometer, decreasing the performance of the ICPMS and requiring frequent cleaning [5]. Most of these limitations can be overcome by using ion exchange chromatography with ICPMS, because organic complexing reagents and organic solvents are generally not required. However, the use of various buffers and salts to control the ionic strength or $\mathrm{pH}$ in ion exchange also causes severe problems with the ICPMS due to salt deposition on the cones. These reagents should be avoided if possible.

Another problem when using the ICPMS as the vanadium detector is the formation of polyatomic ions in the plasma with the same mass as vanadium. The isobaric interference with the ${ }^{51} \mathrm{~V}$ isotope $(99.75 \%$ abundance) is the $\left[{ }^{35} \mathrm{Cl}^{16} \mathrm{O}\right]^{+}$ion $[1,26,31,32]$. However, this polyatomic ion can be eliminated by the introduction of a reaction cell or a collision cell between the plasma and the quadrupole analyzer $[1,26,31,32]$.

Vanadium is one of 12 redox sensitive elements, also including arsenic, antimony, chromium, copper, iron, manganese, molybdenum, rhenium, selenium, tungsten, and uranium, that we are studying in order to develop an empirical relationship for predicting the redox states of many trace elements in groundwater near nuclear or other waste sites, based on the measurement of the speciation of a few. Such a relationship is needed since most attempts to predict trace element speciation in natural waters by measuring the $\mathrm{E}_{\mathrm{H}}$ and $\mathrm{pH}$ have been unsuccessful [33-37]. In this report, we present a fast, selective, and sensitive method for establishing the speciation of vanadium using IC-ICPMS. The main advantages of the method include the direct injection of groundwater samples, without preconcentration or chelation, and the use of a dilute nitric acid mobile phase. This combination keeps the build-up of solids in the ultrasonic nebulizer, the torch, and the entrance cones of the ICPMS to a minimum, thereby contributing to low instrument down-time.

\section{EXPERIMENTAL}

\subsection{Chemicals and Solutions}

Ultrapure water with a specific resistance of $18.2 \mathrm{M} \Omega$ $\mathrm{cm}^{-1}$ was obtained from a Milli-Q Element A10 apparatus (Millipore, Bedford, MA, USA) and used to prepare the mobile phase and all calibration solutions. All V(IV) solutions were prepared from a $10 \mathrm{mg} \mathrm{L}^{-1}$ stock solution in $5 \% \mathrm{HNO}_{3}$ (Spex CertiPrep, Metuchen, NJ, USA) and all $\mathrm{V}(\mathrm{V})$ solutions prepared from $\mathrm{NaVO}_{3}(96 \%$, Alfa Aesar, Ward Hill, MA, USA). The total vanadium was determined in a routine where 54 elements were determined in all field samples by ICPMS, without the intervention of IC. Multielement standards (Spex CertiPrep, Metuchen, NJ, USA) were used as calibration standards. Yttrium (Y 99.999\%) $1000 \mathrm{mg} \mathrm{L}^{-1}$ solution, High-Purity Standards, Charleston, SC, USA) served as the internal standard. All solutions were stored in the dark in a refrigerator at $4 \pm 1^{\circ} \mathrm{C}$ and the calibration solutions were prepared daily. The mobile phase $\left(1.5 \% \mathrm{v} / \mathrm{v} \mathrm{HNO}_{3}\right)$ was prepared by the dilution of sub-boiling distilled in quartz $16 \mathrm{M} \mathrm{HNO}_{3}$ (Seastar Chemicals INC., Sydney, BC, Canada) with Milli-Q water.

\subsection{Instrumentation}

The ICPMS used was an Elan 6100 with a Dynamic Reaction Cell (DRC) (PerkinElmer-Sciex, Norwalk, CT, USA). All liquid samples were introduced to the ICPMS with a Cetac U6000AT ${ }^{+}$ultrasonic nebulizer (Cetac Technologies, Omaha, NE, USA). The vanadium oxidation state species were separated by ion chromatography using a system which included a Dionex GP 50 Gradient pump (Dionex Corporation, Sunnyvale, CA, USA), a Dionex IonPac CG5A guard column $(4 \times 50 \mathrm{~mm})$, a Dionex IonPac CS5A $(4 \times 250 \mathrm{~mm})$ analytical column, and a six-way valve with a $200 \mu \mathrm{L}$ loop. The effluent tubing from the analytical column was connected to the ultrasonic nebulizer whose output entered the ICPMS. The total vanadium analysis was carried out by introducing water samples directly to the ultrasonic nebulizer using an autosampler (AS93 Plus, PerkinElmer), without passing through the ion exchange column.

\subsection{Sampling}

Groundwater samples were collected from: 1) wells drilled by the Nye County Early Warning Drilling Program (NCEWDP) in the Amargosa Valley, NV, USA and, 2) springs in the Ash Meadows National Wildlife Refuge, NV, USA. The well samples were collected after pumping out a minimum of three well volumes and stabilization of $\mathrm{pH}$, conductivity, and dissolved oxygen. Spring water was pumped through Teflon tubing from as near as possible to the source of discharge. All water samples were filtered through an inline $0.45 \mu \mathrm{m}$ filter (AquaPrep, Pall, East Hills, NY, USA) and collected under an inert atmosphere (argon).

The samples were collected in $250 \mathrm{~mL}$ polyethylene wash bottles (Nalgene, Rochester, NY, USA), modified as shown in Fig. (1). Before collection trips, the sample bottles were rinsed five times with $18.2 \mathrm{M} \Omega \mathrm{cm}^{-1}$ deionized water and allowed to air dry in a laminar flow hood. They were then stored in zip-lock bags until needed. Before being taken into the field, they were fitted with the introduction tube and clamp, filled with argon, and rebagged. The water samples were collected by connecting the output from the $0.45 \mu \mathrm{m}$ filter to the wash bottle spout (see Fig. 1), while partially loosening the top in order to allow argon to be expelled as the water flowed into the bottom of the bottle. Sample introduction was stopped before all of the argon was displaced, then the cap was tightened leaving the sample covered with argon, the plastic clamp closed, and the 0.45 $\mu \mathrm{m}$ filtered water-source removed. The sample bottles were returned to the zip-lock plastic bags which were flushed with argon. The bagged samples were placed in coolers with frozen ice packs and transferred to the laboratory where they were stored in argon-filled zip-lock bags in a refrigerator at $4 \pm 1{ }^{\circ} \mathrm{C}$ until analysis, usually one to three days. Duplicate samples were also collected from the same wells and springs. The $\mathrm{E}_{\mathrm{H}}$ and $\mathrm{pH}$ of all waters were measured in the field immediately using an oxidation reduction potentiometer (Hach, Loveland, CO, USA) and a $\mathrm{pH}$ meter (model HQ 40d; Hach, Loveland, CO, USA). Samples were collected at all locations for other studies, including measurement of the 
major ions including chloride, which might have some bearing on the formation of isobaric ions during the analysis of vanadium.

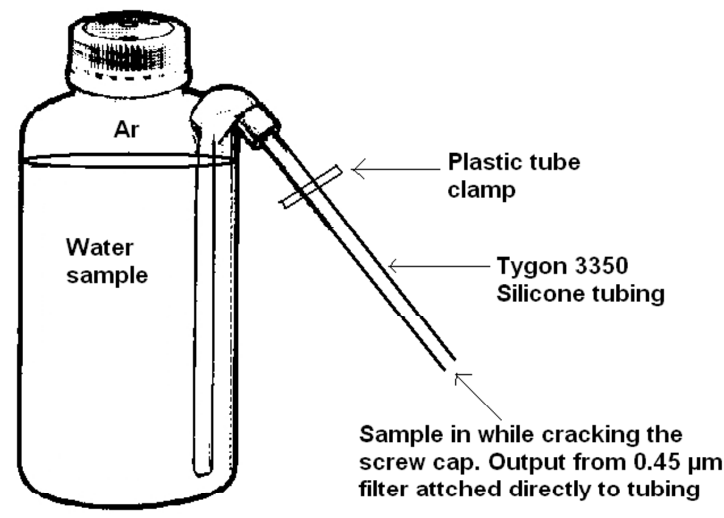

Fig. (1). Sample collection bottle.

\subsection{Vanadium Speciation Analysis}

First, the sample bottle, stored in an argon-filled plastic bag, was removed from the $4^{\circ} \mathrm{C}$ refrigerator and placed in a glove box (Erlab, North Andover, MA, USA), which was continually purged with argon. The bottle was removed from the plastic bag and the plastic clamp opened. The bottle was then squeezed to expel a few milliliters of sample into a 20 $\mathrm{mL}$ styrofoam disposable beaker (VWR Scientific Products, West Chester, PA, USA). When pressure on the bottle was released, argon flowed in to replace the expelled sample. The plastic clamp was closed and the sample bottle placed into its argon-filled zip-lock bag, and returned to the refrigerator. Next, a $3 \mathrm{~mL}$ disposable syringe (Becton Dickson \& Co., Franklin Lakes, NJ, USA) was filled from the expelled sample in the argon glove box. The syringe was removed from the glove box and immediately attached to the IC injection valve. The $200 \mu \mathrm{L}$ sample loop was flushed with sample and closed. When the valve was turned to introduce the sample into the mobile phase, a signal was sent to the ICPMS and the run was started. Table 1 summarizes the chromatographic conditions and ICPMS parameters. The signal at $\mathrm{m} / \mathrm{z}$ ratio of 51 was monitored for quantification $\left({ }^{51} \mathrm{~V}\right.$ is $99.75 \%$ abundant $)$. An external calibration method was used with five points for both $\mathrm{V}(\mathrm{IV})$ and $\mathrm{V}(\mathrm{V})$. The $\mathrm{R}^{2}$ values were required to be $\geq 0.998$. The vanadium concentrations in each oxidation state were calculated based on peak heights. Initial calibration verification solutions, continuing calibration check solutions, reagent blank solutions, spiked sample solutions, and duplicate sample injections were included routinely in the sample train as quality control measures. The stability of the oxidation state species in the $1.5 \% \mathrm{v} / \mathrm{v} \mathrm{HNO}_{3}$ mobile phase over time was investigated and the results are presented in the results and discussion.

\section{RESULTS AND DISCUSSION}

\subsection{Vanadium Speciation Method Development}

A study was conducted to determine the effectiveness of the dynamic reaction cell (DRC) with $\mathrm{NH}_{3}$ as the reaction gas, to destroy $\left[{ }^{35} \mathrm{Cl}^{16} \mathrm{O}\right]^{+}$. This molecular ion is isobaric with
Table 1. Operating Analytical Conditions

\begin{tabular}{|c|c|}
\hline \multicolumn{2}{|c|}{ Chromatographic Conditions } \\
\hline Analytical column & IonPac CS5A (4×250 mm) \\
\hline Guard column & IonPac CG5A $(4 \times 50 \mathrm{~mm})$ \\
\hline Injection volume & $200 \mu \mathrm{L}$ \\
\hline Pressure & 2000 PSI \\
\hline Mobile phase & $1.5 \% \mathrm{v} / \mathrm{v} \mathrm{HNO}_{3}$ \\
\hline Flow rate & $1.50 \mathrm{~mL} \mathrm{~min}^{-1}$ \\
\hline Elution & Isocratic \\
\hline Time of analysis & $5 \mathrm{~min}$ \\
\hline \multicolumn{2}{|c|}{ ICPMS Parameters } \\
\hline ICPMS & Elan 6100 DRC \\
\hline Sample introduction system & Cetac ultrasonic nebulizer model U6000AT \\
\hline RF power & $1.3 \mathrm{~kW}$ \\
\hline Mode & DRC \\
\hline Plasma gas flow & $15.00 \mathrm{~L} \mathrm{~min}^{-1}$ \\
\hline Auxiliary gas flow & $1.10 \mathrm{~L} \mathrm{~min}^{-1}$ \\
\hline Nebulizer gas flow & $1.06 \mathrm{~L} \mathrm{~min}^{-1}$ \\
\hline DRC - cell gas A $\left(\mathrm{NH}_{3}\right)$ & $0.5 \mathrm{~mL} \mathrm{~min}^{-1}$ \\
\hline Internal standard & ${ }^{89} \mathrm{Y}$ (for total vanadium) \\
\hline Isotope monitored ( $\mathrm{m} / \mathrm{z}$ ratio) & 51 \\
\hline
\end{tabular}

${ }^{51} \mathrm{~V}$ and could lead to false positive measurements. Samples of groundwater and standards with vanadium concentrations in the range of $0.05 \mu \mathrm{gL}^{-1}$ to $100 \mu \mathrm{gL}^{-1}$ were analyzed using IC-ICPMS with and without the DRC. The results showed that the background was higher $(\sim 25000 \mathrm{cps})$ with the DRC "off" than with the DRC "on" ( $\sim 5000 \mathrm{cps}$, gas flowing in the cell). When $\mathrm{NaCl}$ solutions covering and exceeding the concentrations found in the environmental water samples $(0$ $100 \mathrm{mgL}^{-1}$ chloride) were injected into the IC-ICPMS with the DRC "off", no false ${ }^{51} \mathrm{~V}$ peaks were observed, and the background was high. Similarly, with the DRC "on", no false peaks were observed and the background was lower. Therefore, the DRC mode was used for all analytical runs, because it reduced the background signal and did not significantly reduce the analytical signal. Figs. $(\mathbf{2}, \mathbf{3})$ show the IC-ICPMS chromatograms obtained for $1 \mu \mathrm{g} \mathrm{L^{-1 }}$ calibration solutions of $\mathrm{V}(\mathrm{IV})$ and $\mathrm{V}(\mathrm{V})$ under the optimized conditions in Table 1 . The detection limit $(3 \sigma ; n=7$ runs $)$ is $0.02 \mu \mathrm{g} \mathrm{L}^{-1}$ for $\mathrm{V}(\mathrm{IV})$ and $0.06 \mu \mathrm{g} \mathrm{L}^{-1}$ for $\mathrm{V}(\mathrm{V})$.

The mobile phase, flowing continuously through the chromatographic-nebulizer-ICPMS system was $1.5 \% \mathrm{v} / \mathrm{v}$ $\mathrm{HNO}_{3}$. One might be concerned about using dilute nitric acid because of its oxidizing properties, and thus the possibility of altering the vanadium speciation during the analysis. However, the clean chromatograms of $1 \mu \mathrm{g} \mathrm{L}^{-1}$ for the two oxidation states in Figs. $(\mathbf{2}, \mathbf{3})$ suggest that contact with the mobile phase does not alter the redox state of vanadium during the 5-minute analysis time. To substantiate this 


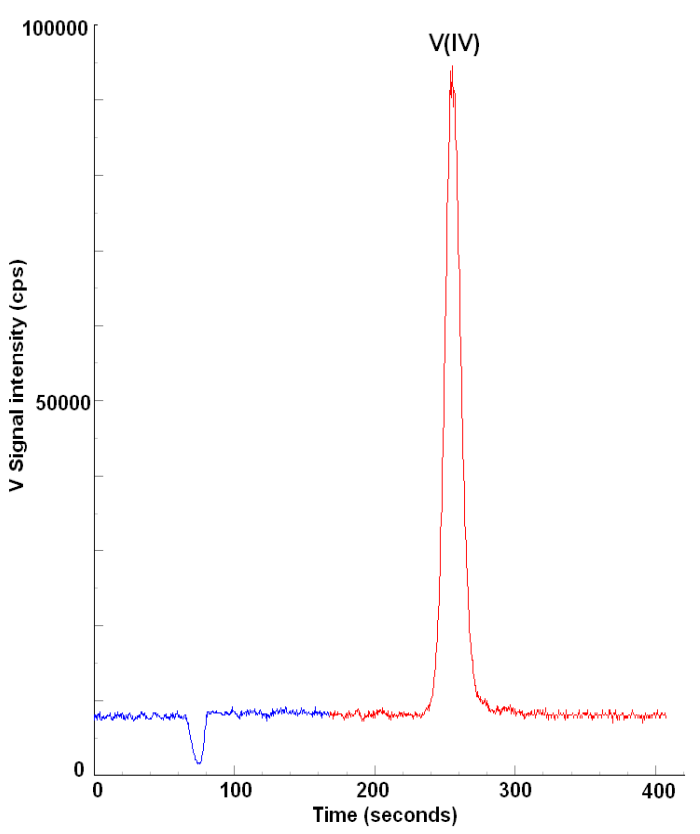

Fig. (2). Chromatogram of a $1 \mu \mathrm{g} \mathrm{L} \mathrm{L}^{-1}$ standard of V(IV) prepared in ultrapure deionized water. Experimental conditions are listed in Table 1.

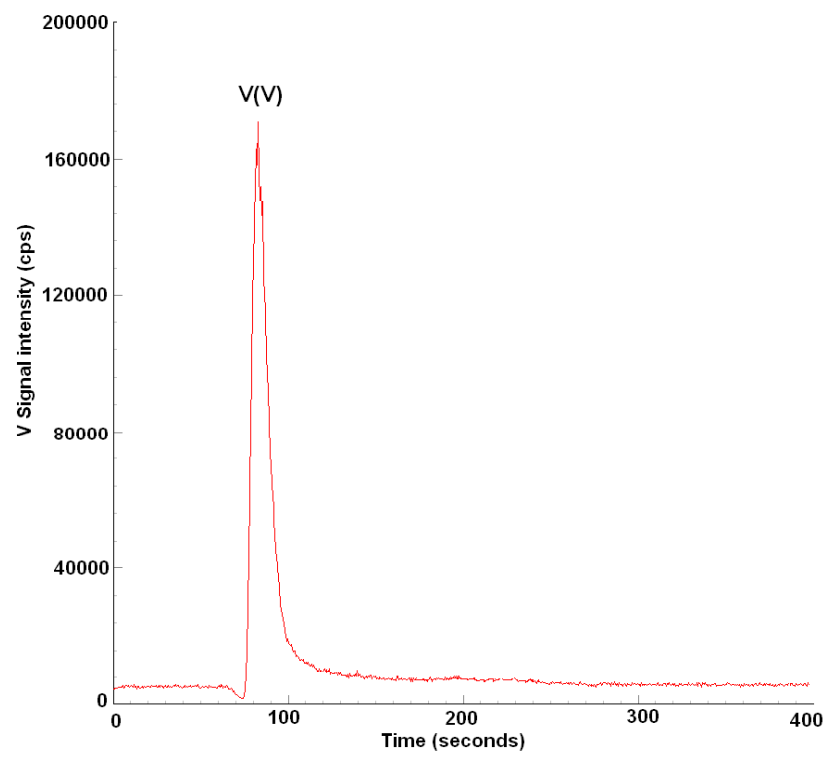

Fig. (3). Chromatogram of a $1 \mu \mathrm{g} \mathrm{L}^{-1}$ standard of $\mathrm{V}(\mathrm{V})$ prepared in ultrapure deionized water. Experimental conditions are listed in Table 1.

observation, the effect of a $1.5 \% \mathrm{v} / \mathrm{v} \mathrm{HNO}_{3}$ on vanadium speciation over a longer time was evaluated. This was performed by preparing $10 \mu \mathrm{g} \mathrm{L}^{-1}$ solutions of $\mathrm{V}(\mathrm{IV})$ and $\mathrm{V}(\mathrm{V})$ in pure water and in $1.5 \% \mathrm{v} / \mathrm{v} \mathrm{HNO}_{3}$. The solutions were analyzed immediately after preparation, and, at $5 \mathrm{hr}, 72$ $\mathrm{hr}$ and 7 days intervals. The results showed that in pure water, $\mathrm{V}(\mathrm{IV})$ converts slowly to $\mathrm{V}(\mathrm{V})$ and is stable in $1.5 \%$. $\mathrm{HNO}_{3}$. Conversely, $\mathrm{V}(\mathrm{V})$ is slowly reduced to $\mathrm{V}(\mathrm{IV})$ in $1.5 \%$
$\mathrm{HNO}_{3}$ and is stable in deionized water. Thus, the use of $1.5 \%$ $\mathrm{HNO}_{3}$ as the mobile phase does not produce a change in the the redox species ratio during the five minute analysis time.

\subsection{Vanadium Speciation in Southern Nevada Groundwater}

The groundwater sampling sites are located near Las Vegas and are given in Figs. $(\mathbf{4}, \mathbf{5})$. The Nye County Early Warning Drilling Program (NCEWDP) is a part of the research umbrella supported by the DOE scientific investigation of Yucca Mountain as a suitable site for the long-term storage of high-level nuclear waste from commercial electrical power reactors and military sources. It has been extensively studied since 1978 and its fate is still unclear (as of 2009). The NCEWDP research targets the complex hydrology of the area located just east of Yucca Mountain. The NCEWDP site is also adjacent to the Nevada Test Site (NTS), where many nuclear devices were tested underground near or in the water table. The redox condition of the groundwater is just one of the minor phases of the overall study of Yucca Mountain and the NTS. The general consensus is that reducing groundwater impedes the movement of most trace elements, including their radioactive isotopes, and oxidizing conditions favor such movement. Water from springs in the Ash Meadows National Wildlife Refuge, located about 60 miles to the northwest of Las Vegas and about 25 miles south of Yucca Mountain, is thought to consist of water originating on the eastern side of the NTS (the Pahranagat Valley) along with recharge from the nearby Spring Mountains, just east of Ash Meadows [38]. It is not known if any component of this water originates from the NTS.

Figs. $(6,7)$ show typical chromatograms of vanadium in groundwater samples from the NCEWDP wells and natural springs of Ash Meadows. Fig. (6) shows the lowest $\mathrm{V}(\mathrm{IV}) / \mathrm{V}(\mathrm{V})$ ratio observed and Fig. (7) shows the highest ratio observed. Although the concentration of vanadium is over twenty times higher in the NCEWDP well than in the Ash Meadows spring, $\mathrm{V}(\mathrm{V})$ is clearly the predominant oxidation state in these chromatograms and, in fact, the predominant species in all of the samples collected from the nine locations in the study.

The vanadium results are found in Table $\mathbf{2}$ for groundwater from wells in the NCEWDP and springs from Ash Meadows. Also listed are the measured $\mathrm{pH}$, measured $\mathrm{E}_{\mathrm{H}}$, sum of the experimental V(IV) and V(V) concentrations, total vanadium by ICPMS (without the IC), the percentage of mass balance, and the percentage of $\mathrm{V}(\mathrm{V})$ in these samples.

The reproducibility of the vanadium redox species measurements can be evaluated by comparing the results obtained for the duplicate samples, which were collected in tandem at $\mathrm{J}-12$ and $33 \mathrm{P}$. The reproducibility of $\mathrm{J}-12$ and $33 \mathrm{P}$ samples were $19 \%$ and $5 \%$ for V(IV) and, $5 \%$ and $7 \%$ for V(V). Spiking experiments (standard additions) were carried out to demonstrate the accuracy of the vanadium concentrations. The average recoveries were $98 \%$ and $102 \%$ for $\mathrm{V}(\mathrm{IV})$ and $\mathrm{V}(\mathrm{V})$ respectively, demonstrating that there are no measurable matrix interferences. 


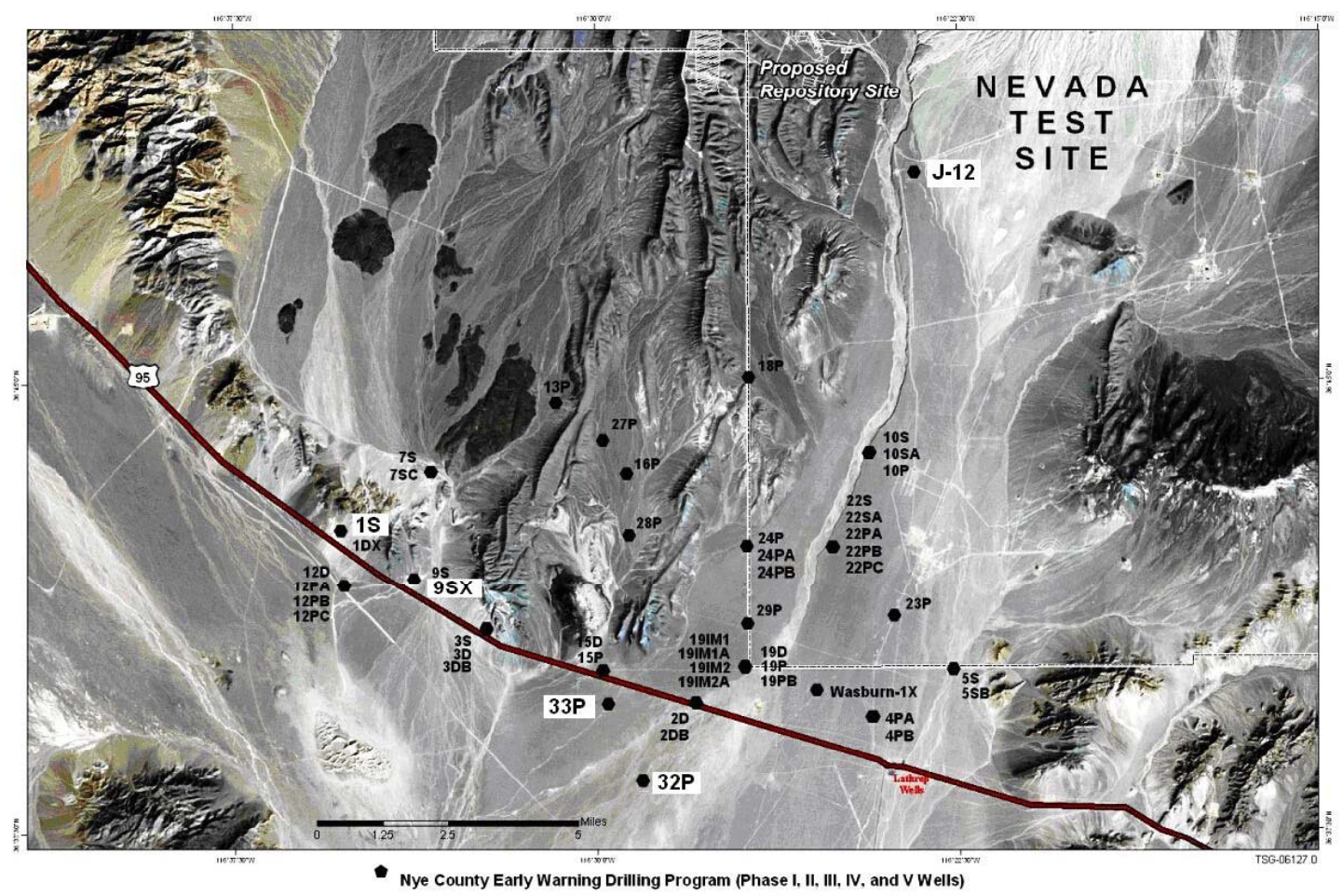

Fig. (4). Map of the NCEWDP well locations on and adjacent to Yucca Mountain and the Nevada Test Site [http://www.nyecounty.com/ewdpmain.htm].

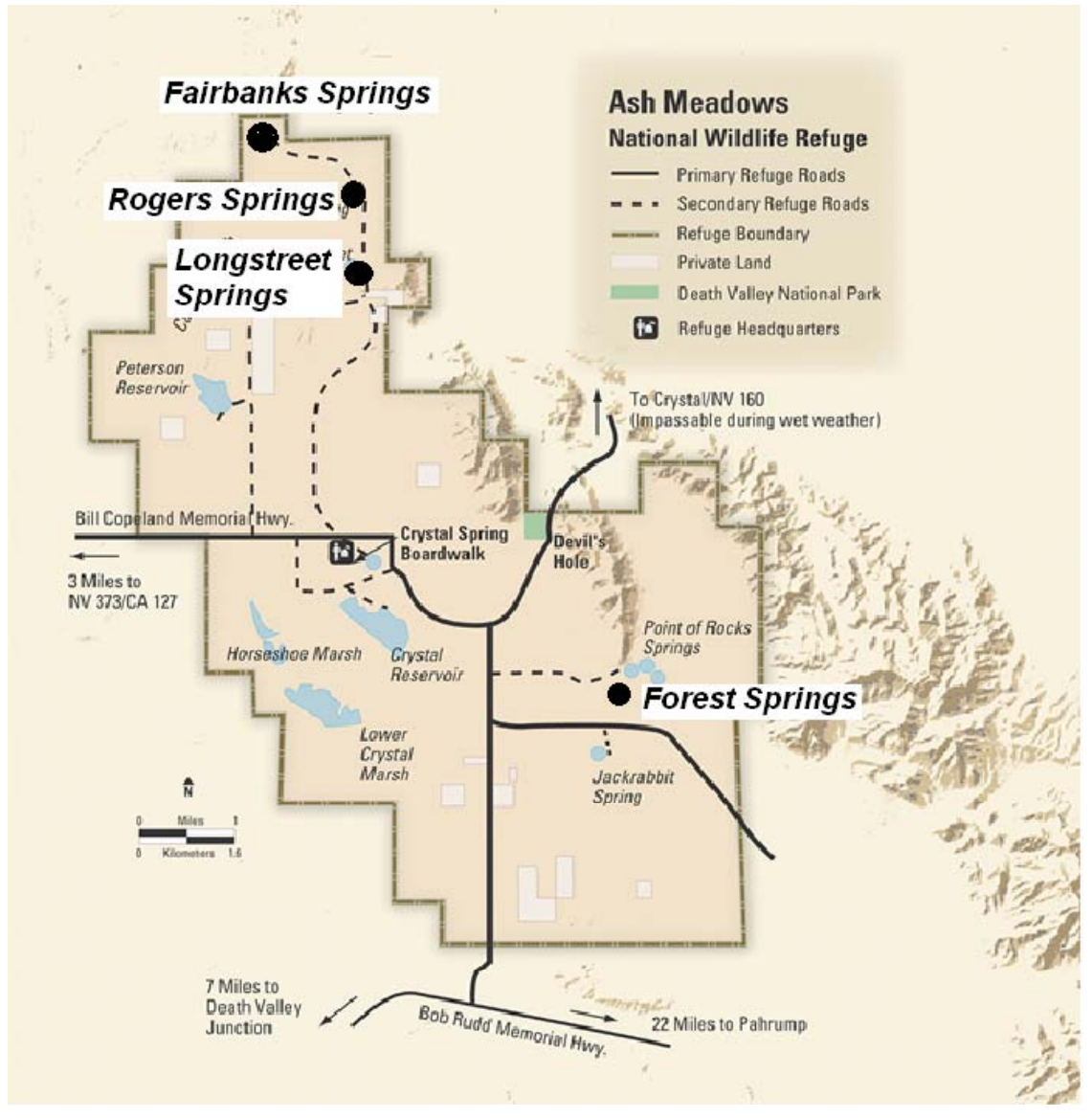

Fig. (5). Map of the Ash Meadows National Wildlife Refuge showing locations of springs. Samples were collected from Fairbanks, Rogers, Longstreet and Forest springs [http://www.fws.gov/desertcomplex/ashmeadows/map.htm]. 


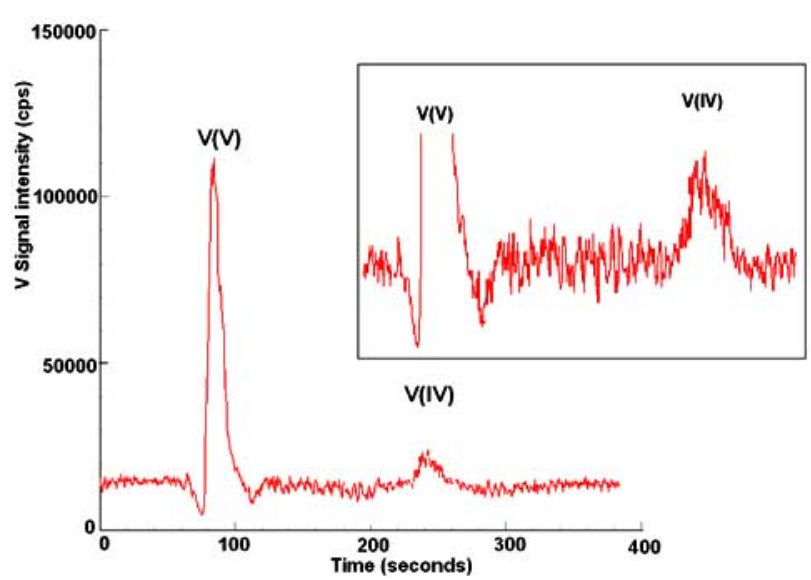

Fig. (6). Chromatogram of vanadium species in groundwater from the NCEWDP (well ID: 32P Deep). Experimental conditions as in Table 1. V(IV) $=0.47 \pm 0.06 \mu \mathrm{g} \mathrm{L}^{-1}$ and $\mathrm{V}(\mathrm{V})=82.1 \pm 0.5 \mu \mathrm{g} \mathrm{L}^{-1}$.

Pentavalent vanadium represents $98 \%$ to $99 \%$ of total vanadium in the well water samples, and $99 \%$ in spring water samples. The sum of total vanadium concentration ranged between $7.0 \pm 0.1 \mu \mathrm{g} \mathrm{L}^{-1}$ and $82.6 \pm 0.5 \mu \mathrm{g} \mathrm{L}^{-1}$ for well water and $3.8 \pm 0.1 \mu \mathrm{g} \mathrm{L}^{-1}$ and $5.8 \pm 0.1 \mu \mathrm{g} \mathrm{L}^{-1}$ for spring water. The total vanadium concentration (without IC) ranged between $7.7 \pm 0.2 \mu \mathrm{g} \mathrm{L}^{-1}$ and $78 \pm 2 \mu \mathrm{g} \mathrm{L}^{-1}$ for well water and $3.5 \pm 0.1 \mu \mathrm{g} \mathrm{L}^{-1}$ and $4.9 \pm 0.1 \mu \mathrm{g} \mathrm{\textrm {L } ^ { - 1 }}$ for spring water. The mass balance calculations comparing the sum of total vanadium (IC-ICPMS) with the total vanadium (ICPMS) ranged between $86 \pm 1 \%$ to $105 \pm 2 \%$ for well water and $90 \pm 10 \%$ to $124 \pm 2 \%$ for spring water.

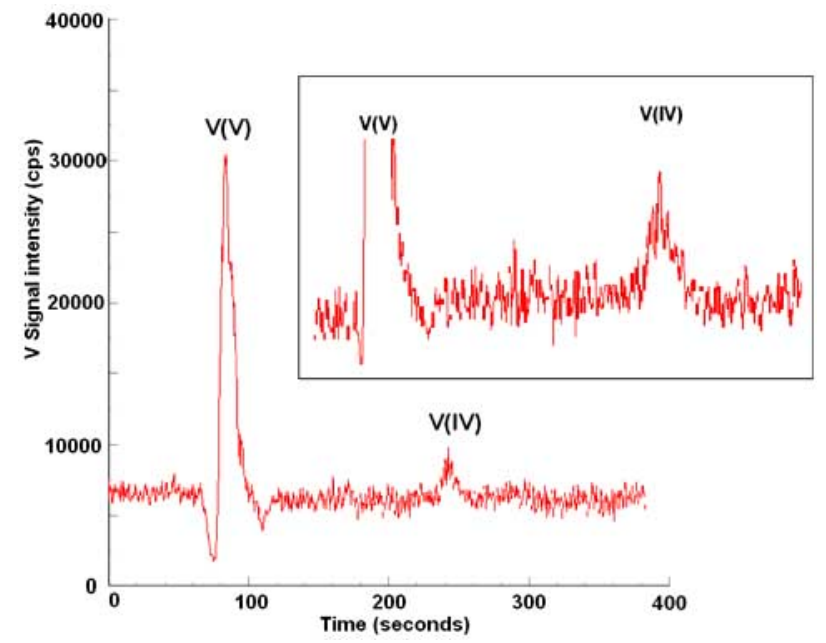

Fig. (7). Chromatogram of vanadium species in groundwater from Ash Meadows (Fairbanks Spring). Experimental conditions as in Table 1. V(IV) $=0.06 \pm 0.02 \mu \mathrm{g} \mathrm{L}^{-1}$ and $\mathrm{V}(\mathrm{V})=4.3 \pm 0.1 \mu \mathrm{g} \mathrm{L}^{-1}$.

Also listed in the last column of the table is the $E_{H}$ calculated from the Nernst relationship shown in equation 1 , where, $E^{0}$ is the standard electrode potential $[8-10,34,39,40]$.

Equation 1

$V O_{2}^{+}+e^{-}+2 H^{+} \Leftrightarrow V O^{2+}+H_{2} O \quad E^{0}=1016 \pm 2 m V$

$E_{H\left(V O_{2}^{+} / V O^{2+}\right)}=E^{0}+59 \log \frac{\left[\mathrm{VO}_{2}^{+}\right]}{\left[\mathrm{VO}^{2+}\right]}-2 \times 59 \times p H$

For the first well, $1 \mathrm{~S}$ Zone $1: \mathrm{E}_{\mathrm{H}}=1016 \mathrm{mV}+99 \mathrm{mV}$ $894 \mathrm{mV}=221 \pm 10 \mathrm{mV}$ compared to the measured value of

Table 2. Vanadium Speciation in Southern Nevada Well Water and Spring Water

\begin{tabular}{|c|c|c|c|c|c|c|c|c|c|}
\hline Sample & $\begin{array}{c}\text { pH } \\
\pm 0.05\end{array}$ & $\begin{array}{c}\mathbf{E}_{\mathrm{H}} \\
\pm 5(\mathrm{mV})\end{array}$ & $\begin{array}{c}\mathrm{V}(\mathrm{IV}) \\
\left(\mu \mathrm{g} \mathrm{L}^{-1}\right)\end{array}$ & $\begin{array}{c}\mathrm{V}(\mathrm{V}) \\
\left(\mu \mathrm{g} \mathrm{L}^{-1}\right)\end{array}$ & $\begin{array}{c}\text { VTot sum } \\
\left(\mu g \mathrm{~L}^{-1}\right)\end{array}$ & $\begin{array}{l}\operatorname{VTot}^{\mathrm{b}} \\
\left(\mu \mathrm{g} \mathrm{L^{-1 }}\right)\end{array}$ & $\begin{array}{c}\text { Mass } \\
\text { Balance(\%) }\end{array}$ & $\begin{array}{c}\mathrm{V}(\mathrm{V}) \\
\%\end{array}$ & $\begin{array}{c}\mathbf{E}_{\mathrm{H}} \text { Calculated } \\
(\mathrm{mV})\end{array}$ \\
\hline \multicolumn{10}{|l|}{ Wells } \\
\hline 1S Zone 1 & 7.58 & 133 & $0.14 \pm 0.03$ & $12.2 \pm 0.2$ & $12.3 \pm 0.2$ & $13.3 \pm 0.1$ & $93 \pm 2$ & $99 \pm 2$ & $221 \pm 10$ \\
\hline 1S Zone 2 & 7.35 & 140 & $0.16 \pm 0.04$ & $8.3 \pm 0.1$ & $8.5 \pm 0.1$ & $8.2 \pm 0.4$ & $103 \pm 5$ & $98 \pm 2$ & $235 \pm 7$ \\
\hline 9SX Zone 2 & 7.76 & 121 & $0.09 \pm 0.04$ & $9.1 \pm 0.1$ & $9.2 \pm 0.1$ & $10.2 \pm 0.3$ & $90 \pm 2$ & $99 \pm 2$ & $210 \pm 30$ \\
\hline 9SX Zone 3 & 8.17 & 132 & $0.07 \pm 0.02$ & $7.7 \pm 0.1$ & $7.8 \pm 0.1$ & $8.1 \pm 0.4$ & $96 \pm 5$ & $99 \pm 2$ & $158 \pm 14$ \\
\hline 9SX Zone 4 & 7.64 & 128 & $0.12 \pm 0.03$ & $9.0 \pm 0.1$ & $9.1 \pm 0.1$ & $10.1 \pm 0.2$ & $91 \pm 2$ & $99 \pm 2$ & $210 \pm 9$ \\
\hline $\mathrm{J}-12$ & 8.23 & 154 & $0.20 \pm 0.04$ & $19.7 \pm 0.3$ & $19.9 \pm 0.3$ & $22.0 \pm 0.1$ & $91 \pm 1$ & $99 \pm 2$ & $148 \pm 12$ \\
\hline J-12 Dup & 8.18 & 154 & $0.24 \pm 0.04$ & $18.7 \pm 0.2$ & $18.9 \pm 0.2$ & $21.9 \pm 0.1$ & $86 \pm 1$ & $99 \pm 2$ & $148 \pm 7$ \\
\hline 33P Deep & 8.37 & 172 & $0.14 \pm 0.04$ & $6.9 \pm 0.1$ & $7.0 \pm 0.1$ & $7.9 \pm 0.3$ & $89 \pm 4$ & $98 \pm 2$ & $114 \pm 8$ \\
\hline 33P Deep Dup & 8.30 & 164 & $0.13 \pm 0.03$ & $7.4 \pm 0.1$ & $7.5 \pm 0.1$ & $7.7 \pm 0.2$ & $98 \pm 3$ & $98 \pm 2$ & $126 \pm 7$ \\
\hline 33P Int & 8.34 & 167 & $0.18 \pm 0.04$ & $9.2 \pm 0.1$ & $9.4 \pm 0.2$ & $10.3 \pm 0.2$ & $91 \pm 3$ & $98 \pm 2$ & $119 \pm 7$ \\
\hline 32P Deep & 8.49 & 163 & $0.47 \pm 0.06$ & $82.1 \pm 0.5$ & $82.6 \pm 0.5$ & $78 \pm 2$ & $105 \pm 2$ & $99 \pm 1$ & $132 \pm 12$ \\
\hline $32 \mathrm{P}$ Int & 8.33 & 167 & $0.22 \pm 0.05$ & $20.4 \pm 0.4$ & $20.6 \pm 0.4$ & $21.2 \pm 0.3$ & $97 \pm 2$ & $99 \pm 3$ & $135 \pm 13$ \\
\hline \multicolumn{10}{|l|}{ Springs } \\
\hline Forest & 8.22 & 165 & $0.05 \pm 0.01$ & $5.7 \pm 0.1$ & $5.8 \pm 0.1$ & $4.6 \pm 0.1$ & $124 \pm 2$ & $99 \pm 1$ & $154 \pm 20$ \\
\hline Longstreet & 8.70 & 138 & $0.06 \pm 0.03$ & $4.3 \pm 0.1$ & $4.4 \pm 0.1$ & $4.9 \pm 0.1$ & $90 \pm 10$ & $99 \pm 3$ & $87 \pm 20$ \\
\hline Rogers & 8.14 & 172 & $0.05 \pm 0.03$ & $3.7 \pm 0.1$ & $3.8 \pm 0.1$ & $3.5 \pm 0.1$ & $107 \pm 4$ & $99 \pm 4$ & $154 \pm 30$ \\
\hline Fairbanks & 8.47 & 165 & $0.06 \pm 0.02$ & $4.3 \pm 0.1$ & $4.4 \pm 0.1$ & $3.6 \pm 0.1$ & $120 \pm 5$ & $99 \pm 4$ & $114 \pm 20$ \\
\hline
\end{tabular}


133. The species ratio yields 99 , an order of magnitude lower than the other two wells and in order to get a value of 133 from the relationship in Equation 1, the species ratio would have to be 11 , or about $10 \%$ of the vanadium would have to be found in the reduced state. Clearly, this is not the case for this water sample. On the other hand, the calculated and measured $E_{H}$ values are within experimental error for about half of the sites, in most cases due to the very low concentrations of V(IV) and the associated high error. Even though the lower limits of detection for vanadium (IV) and (V) are quite good, $0.02 \mu \mathrm{g} \mathrm{L}^{-1}$ for V(IV) and $0.06 \mu \mathrm{g} \mathrm{L}^{-1}$ for $\mathrm{V}(\mathrm{V})$, the limit for V(IV) would have to be improved, if this element could be used to rigorously evaluate the relationship between the measured and calculated $\mathrm{E}_{\mathrm{H}}$.

\section{CONCLUSIONS}

A method was developed for measuring vanadium (IV) and $(\mathrm{V})$ in groundwater by IC-ICPMS, using cation exchange and $1.5 \% \mathrm{v} / \mathrm{v} \mathrm{HNO}_{3}$ as the mobile phase. It is fast (about five minutes), selective, and sensitive, with detection limits of $0.02 \mu \mathrm{g} \mathrm{L}^{-1}$ for $\mathrm{V}(\mathrm{IV})$ and $0.06 \mu \mathrm{g} \mathrm{L}^{-1}$ for $\mathrm{V}(\mathrm{V})$. No chelating agents are involved. This combination keeps the build-up of solids in the ultrasonic nebulizer, the torch, and the entrance cones of the ICPMS to a minimum, thereby contributing to low instrument down-time. The pentavalent oxidation state of vanadium is, by far, the dominant species in all of the groundwater samples analyzed in Southern Nevada.

\section{ACKNOWLEDGEMENTS}

This research was funded by the U.S. Department of Energy. All experiments were carried out at the Harry Reid Center for Environmental Studies, University of Nevada, Las Vegas.

\section{REFERENCES}

[1] Aureli, F.; Ciardullo, S.; Pagano, M.; Raggi, A.; Cubadda, F. Speciation of vanadium(IV) and (V) in mineral water by anion exchange liquid chromatography-inductively coupled plasma mass spectrometry after EDTA complexation. J. Anal. Atom. Spectrom. 2008, 23, 1009.

[2] Colina, M.; Gardiner, P.H.E.; Rivas, Z.; Troncone, F. Determination of vanadium species in segments, mussel and fish muscle tissue samples by liquid chromatography-inductively coupled plasma-mass spectrometry. Anal. Chim. Acta, 2005, 538, 107.

[3] Fiorentino, C. E.; Paoloni, J.D.; Sequera, M.E.; Arosteguy, P. The presence of vanadium in groundwater of southeastern extreme pampean region of Argentina: relationship with other chemical elements. J. Contam. Hydrol., 2007, 93, 122.

[4] Minell, L.; Veschetti, E.; Giammanco, S.; Mancini, G.; Ottaviani, M. Vanadium in Italian waters: monitoring and speciation of V(IV) and V(V). Microchem. J., 2000, 67, 83.

[5] Pyrzynska, K.; Wierzbicki, T. Determination of vanadium species in environmental samples. Talanta, 2004, 64, 823.

[6] Stohs, S.; Bagchi, D. Oxidative mechanisms in the toxicity of metal ions. Free Radic. Biol. Med., 1995, 18, 321.

[7] IARC Monographs on the Evaluation of Carcinogenic Risk to Humans, Cobalt in Hard Metals and Cobalt Sulfate, Gallium Arsenide, Indium Phosphide, and Vanadium Pentoxide. International Agency for Research on Cancer, Lyon, France, 2006, Vol. 86.

[8] Bodin, S.; Godet, A.; Matera, V.; Stienmann, P.; Vermeulen, J.; Gardin, S.; Adatte, T.; Coccioni, R.; Follmi, K.B. Enrichment of redox-sensitive trace metals $(\mathrm{U}, \mathrm{V}, \mathrm{Mo}, \mathrm{As})$ associated with the late Hauterivian Faraoni oceanic anoxic event. Int. J. Earth Sci., 2007, $96,327$.
[9] Morford, J.1; Emerson, S. The geochemistry of redox sensitive trace metals in sediments. Geochim. Cosmochim. Acta, 1999, 63, 1735 .

[10] Schuring, J.; Cshulz, H.D.; Fischer, W.R.; Bottcher, J.; Duijnisveld, W.H.M. Redox: Fundamentals, Processes, and Applications, Springer-Verlag: Berlin, 2000.

[11] Wehrli, B.; Stumm, W. Vanadyl in natural waters: Adsorption and hydrolysis promote oxygenation. Geochim. Cosmochim. Acta, 1989, 53, 69 .

[12] Chen, Z.; Rahman, M.; Naidu, R. Speciation of vanadium by anionexchange chromatography with inductively coupled plasma mass spectrometry and confirmation of vandium complex formation using elecrospray mass spectrometry. J. Anal. Atom. Spectrom, 2007, 22, 811 .

[13] Chen, Z. L.; Owens, G. Trends in speciation analysis of vanadium in environmental samples and biological fluids - A review. Anal. Chim. Acta, 2008, 607, 1.

[14] Chen, Z.; Owens, G.; Naidu, R. Confirmation of vanadium complex formation using electrospray mass spectrometry and determination of vanadium speciation by sample stacking capillary electrophoresis. Anal. Chim. Acta, 2007, 585, 32.

[15] Vachirapatama, N.; Dicinoski, G. W.; Townsend, A.T.; Haddad, P.R. Determination of vanadium as 4-(2-pyridylazo)resorcinolhydrogen peroxide ternary complexes by ion-interaction reversedphase liquid chromatography. J. Chromatogr. A, 2002, 956, 221.

[16] Liu, B.; Liu, L.; Cheng, J. Analysis of inorganic cations as their complexes by capillary electrophoresis. J. Chromatogr. A, 1999, $834,277$.

[17] Kitazumi, I.; Nakashima, Y.; Himeno, S. Simultaneous electrophoretic determination of vanadium(V) and vanadium(IV) based on the complex formation with a $\mathrm{Mo}(\mathrm{VI})-\mathrm{P}(\mathrm{V})$ reagent. $J$. Chromatogr. A, 2001, 939, 123.

[18] Padarauskas, A.; Schwedt, G. Capillary electrophoresis in metal analysis. Investigations of multi-elemental separation of metal chelates with aminopolycarboxylic acids. J. Chromatogr. A, 1997, 773,351

[19] Tsai, S. J.; Hsu, S. Speciation of vanadium(V) and vanadium(IV) with 4-(2-pyridylazo) resorcinol by using high-performance liquid chromatography with spectrophotometric detection. Analyst, 1994, $119,403$.

[20] Oszwaldowski, S.; Jarosz, M. RP-HPLC study of redox equilibria in vanadium-PAR binary and ternary systems: Direct determination of vanadium in steel. Mikrochim. Acta, 1997, 126, 241.

[21] Oszwaldowski, S.; Lipka, R.; Jarosz, M. Sensitive reversed-phase liquid chromatographic determination of hydrogen peroxide and glucose based on ternary vanadium(V)-hydrogen peroxide-2-(5bromo-2-pyridylazo)-5-diethylaminophenol system. Anal. Chim. Acta, 2000, 421, 35 .

[22] Nagaosa, Y.; Kimata, Y. High-performance liquid chromatography with electrochemical detection for the determination of vanadium(V) in river water and mussel samples. Anal. Chim. Acta, 1996, 327, 203.

[23] Vachirapatama, N.; Jirakiattikul, Y.; Dicinoski, G.; Townsend, A.T.; Haddad, P.R. On-line preconcentration and sample clean-up system for the determination of vanadium as a 4-(2-pyridylazo) resorcinol-hydrogen peroxide ternary complex in plant tissues by ion-interaction high performance liquid chromatography. Anal. Chim. Acta, 2005, 543, 70.

[24] Wann, C.; Jiang, S. Determination of vanadium species in water samples by liquid chromatography-inductively coupled plasma mass spectrometry. Anal. Chim. Acta, 1997, 357, 211.

[25] Tanner, S.D.; Baranov, V.I.; Volkopf, U. A dynamic reaction cell for inductively coupled plasma mass spectrometry (ICP-DRC-MS). J. Anal. Atom. Spectrom., 2000, 15, 1261.

[26] Chery, C.C.; Cremer, K.D.; Cornelis, R.; Vahaecke, F.; Moens, L. Optimisation of ICP-dynamic reaction cell-MS as a specific detector for the speciation analysis of vanadium at therapeutic levels of serum. J. Anal. Atom. Spectrom,. 2003, 18, 113.

[27] Liu, E.; Liu, Y.; Cheng, J. Ultrasensitive chemiluminescence detection of vanadium(IV) by capillary elecrophoresis. Anal. Chim. Acta, 2002, 456, 177.

[28] Wuilloud, R.G.; Wuilloud, J.C.; Olsina, R.A.; Martinez, 1.D. Speciation and preconcentration of vanadium(V) and vanadium(IV) in water samples by flow injection-inductively coupled plasma optical emission spectrometry and ultrasonic nebulization. Analyst, 2001, 126,715 . 
[29] Peng, J.; Liu, S.; Deng, C. Separation and determination of trace amounts of aluminium(III), vanadium(V), iron(III), copper(II) and nickel(II) with CALKS and PAR by RP-HPLC. Anal. Sci., 2005, 21, 259.

[30] Yeh, C.; Jiang, S. Speciation of V, Cr and Fe by capillary electrophoresis-bandpass reaction cell inductively coupled plasma mass spectrometry. J. Chromatogr. A, 2004, 1029, 255.

[31] Latino, J.; Neubauer, K.; Wolf, R.F. Advantages of dynamic bandpass tuning in dynamic reaction cell ICP-MS. Atom. Spectrosc., 2001, 22, 306.

[32] Padarauskas, A. Derivatization of inorganic ions in capillary electrophoresis. Electrophoresis, 2003, 24, 2054.

[33] Stumm, W.; Morgan, J.J. Aquatic Chemistry. Chemical Equilibria and Rates in Natural Waters, $3^{\text {rd }}$ ed.; John Wiley \& Sons, Inc., New York, 1996.

[34] Lindberg, R.D.; Runnels, D.D. Groundwater redox reactions: An analysis of equilibrium state applied to Eh measurements and geochemical modeling. Science, 1984, 225, 925.
[35] Frevert, T. Can redox conditions in natural waters be predicted by a single parameter?. Schweiz. Z. Hydrol., 1984, 46, 269.

[36] Stumm, W. Interpretation and measurement of redox intensity in natural waters. Schweiz. Z. Hydrol., 1984, 46, 291.

[37] Stefansson, A.; Arnorsson, S.; Sveinbjornsdottir, A.E. Redox reactions and potentials in natural waters at disequilibrium. Chem. Geol., 2005, 2, 289.

[38] Johannesson, K.H.; Stetzenbach, K.; Hodge, V.F. Delineation of ground-water flow systems in the southern great basin using aqueous rare earth element distributions. Geochim. Cosmochim. Acta, 1997, 61, 3605.

[39] Fiore, M.; Orecchio, S.; Romano, V.; Zingales, R. Redox potentials of vanadium-containing couples. Part 3: The formal redox potential of the $\mathrm{V}^{3+}-\mathrm{V}^{2+}$ couple. J. Chem. Soc. Dalton Trans., 1993, 5, 799.

[40] Holm, T.R.; Curtiss, C.D. A comparison of oxidation-reduction potentials calculated from the $\mathrm{As}(\mathrm{V}) / \mathrm{As}(\mathrm{III})$ and $\mathrm{Fe}(\mathrm{III}) / \mathrm{Fe}(\mathrm{II})$ couples with measured platinum-electrode potentials in groundwater. J. Contam. Hydrol., 1989, 5, 67.

(C) Gamage et al.; Licensee Bentham Open.

This is an open access article licensed under the terms of the Creative Commons Attribution Non-Commercial License (http://creativecommons.org/licenses/by$\mathrm{nc} / 3.0 /$ ) which permits unrestricted, non-commercial use, distribution and reproduction in any medium, provided the work is properly cited. 